\title{
Low Pay, In-Work Poverty and Economic Vulnerability
}

\author{
Bertrand Maître, Brian Nolan and Christopher T. Whelan
}

\section{Introduction}

As earlier chapters have brought out, the relationship between low pay and poverty is a complex one: low pay for an individual earner may or may not be associated with poverty and disadvantage for the household in which they live (as also brought out in previous studies such as Nolan and Marx, 2000, Gardiner and Millar, 2006, Nolan, 2008, Marx and Verbist, 2008, Gießelmann and Lohman, 2008). Over and above their individual earnings, household circumstances - most importantly the number of other earners as well as dependents - and the social protection and tax systems are central to whether individual low pay means household-level disadvantage. Comparative analysis across countries and over time provides a window into the forces at work and the role of institutions in particular. This chapter sets out findings from such a comparative analysis of low pay and poverty based on EU-SILC, covering the period from before the onset of the Crisis up to 2013 and concentrating on full-time full-year workers. ${ }^{1}$

This focus on full-time full-year workers is important because of the variety of ways in which the relationship between low pay and in-work poverty may be captured and analysed. As highlighted in earlier chapters, and in recent studies such as Hallerod et al (2015), in using EU-SILC the poverty status of a household is generally assessed on the basis of income measured over the period of a year, which for most countries is the previous calendar year. In assessing whether the individual is counted as 'in work' and in low pay, on the other hand, one could be referring to persons who worked for as little as 1 month (Marx et al, 2012) out of the previous 12, for at least 6 or 7 months (as in e.g. Pena-Casa and Latta, 2004, Bardone and Guoio, 2005, Lohman, 2009, Larsson and Hallerod, 2011, Marx and Nolan, 2014), or for all 12 months (Maître, Nolan and Whelan, 2012).

\footnotetext{
${ }^{1}$ For 2006 we draw on Maître, Nolan and Whelan (2012), while the results for EU-SILC 2013 are based on new analyses carried out for present purposes and described in detail in Maître, Nolan and Whelan (2016).
} 
Thus, in assessing the risk of poverty by employment status, the European Social Inclusion Process indicators presented by Eurostat in the Social Inclusion database count working-age individuals as 'in employment' if they spent the more than half of the reference year in that status. The widely-quoted figures on the extent of in-work poverty - the percentage of those 'in employment' who are in households with incomes below the $60 \%$ of median threshold - refer to such individuals. When inwork poverty is measured that way, low (hourly) pay when in work may be conflated with low hours worked in the year as contributors to low annual earnings and in-work poverty, and it is difficult to distinguish the underlying causal mechanisms. Part-time employees and those who work for less than 52 weeks in the year are at enhanced risk of poverty, as brought out in other chapters, and are extremely important groups to study. So are the self-employed, a heterogenous group for whom rates of in-work poverty may also be high, although reliable measurement of their incomes, and indeed the meaning of 'low pay', is more problematic. In concentrating in this chapter on full-time full-year employeess, one can be clear that low annual earnings reflect low rates of pay, enabling a more transparent picture to be presented.

As far as the earnings variable to be used is concerned, current gross monthly earnings and usual hours of work are sometimes available in EU-SILC, allowing gross hourly earnings to be derived, but this is the case only for a minority of countries. By contrast, most of the countries in EU-SILC have provided information on total non-cash employee income for the previous year, so that is the core variable on which we rely. To measure low pay we follow conventional practice in using a threshold of two-thirds of median earnings; importantly, that median is calculated here over full-time full-year employees only, and so represents a higher earnings threshold than the median calculated over all employees. We start by presenting estimates of the overall extent of low pay for full-time full-year workers, and how that varies by individual and household characteristics. We then analyse how many of these low paid employees are living in households at risk of (relative income) poverty, and the characteristics associted with an enhanced poverty risk in those terms. We then consider the picture produced when one goes beyond relative income poverty to focus on a broader measure of household economic vulnerability. Maître, Nolan and Whelan, (2012), 


\section{Low Pay Before and Through the Crisis}

We first look in Table 1 at the extent of low pay for full-time full-year employees, measured on this basis, for the $22 \mathrm{EU}$ or Associate (Iceland and Norway) countries for which this measure can be derived from EU-SILC for 2006 and the 26 countries (with Greece, Italy, Latvia and Portugal now added) for which it can be derived for 2013. The 2006 round can be taken as representing the situation when employment levels were approaching a peak in a considerable number of countries but before the onset of the Crisis in 2007-08, while 2013 is the latest available at the time of writing.

Table 1: Low pay for full-time full year employees

\begin{tabular}{|c|c|c|}
\hline & \multicolumn{2}{|c|}{$\%$ with annual earnings below two-thirds median } \\
\hline & 2006 & 2013 \\
\hline$\overline{\text { Austria }}$ & 1016.3 & 1919.7 \\
\hline Belgium & 10.1 & 10.6 \\
\hline Cyprus & 22.1 & 23.4 \\
\hline Czech Republic & 17.7 & 17.2 \\
\hline Germany & 22.4 & 22.4 \\
\hline Denmark & 11.4 & 9.2 \\
\hline Estonia & 22.8 & 22.5 \\
\hline Greece & & 13.1 \\
\hline Spain & 17.2 & 20.1 \\
\hline Finland & 11.1 & 8.9 \\
\hline France & 11.1 & 10.5 \\
\hline Hungary & 22.7 & 15.2 \\
\hline Ireland & 22.3 & 23.8 \\
\hline Italy & & 14.7 \\
\hline Iceland & 20.7 & 17.4 \\
\hline Lithuania & 26.7 & 27.7 \\
\hline Luxembourg & 28.4 & 28.9 \\
\hline Latvia & & 26.2 \\
\hline The Netherlands & 13.9 & 14.5 \\
\hline Norway & 14.5 & 15.7 \\
\hline Poland & 23.1 & 20.1 \\
\hline Portugal & & 12.1 \\
\hline Sweden & 15.6 & 12.2 \\
\hline Slovenia & 19.0 & 18.2 \\
\hline Slovakia & 16.0 & 16.5 \\
\hline UK & 19.4 & 22.1 \\
\hline
\end{tabular}

Looking first at 2006, the percentage of these employees below the two-thirds of median threshold ranged from a low of $10-11 \%$ in Belgium, Denmark, Finland and 
France up to a high of $27-28 \%$ in Lithuania and Luxembourg. If one thinks in terms of the conventional categorisation into welfare regimes, Denmark and Finland from the Social Democratic regime had the lowest rates, while Norway and Sweden were also relatively low at $15 \%$, though Iceland was at $22 \%$. Among corporatist counties, Belgium, France and the Netherlands had low levels of 10-14\%, Austria had 16\%, but Germany was higher at 22\% and Luxembourg among the highest. Ireland and the UK, representatives of the Anglo-Saxon regime, were well above average at 19-22\%. Among the Southern/Mediterranean countries Spain was at 17\% while Cyprus was at $22 \%$; the relevant data was not available for Greece, Italy or Portugal for that year. Among the post-socialist countries rates were generally high: Slovakia, Slovenia and the Czech Republic, among the more affluent of these countries, had rates of 16-19\%, Hungary, Poland and Estonia were higher at 23\%, at Lithuania joint highest at $27 \%$. So while there are some difference across the regimes in the average rate of low pay, there is also considerable variation within those country groupings.

When we then compare 2013 with 2006, what is striking is that the pattern is so similar, despite the economic turmoil in the intervening years. The extent of low pay is not markedly different in a majority of countries. Where it is different, countries where the rate has risen - Austria, Cyprus, Norway, Spain, and the UK - are balanced by ones where it has fallen, including Denmark, Finland, Poland and Sweden, as well as Hungary and Iceland where major declines were registered. In some of these countries the overall employment level, and the proportion of full-time full-year workers, will have been dramatically affected by the Crisis, so the underlying population of may have changed, but in most countries the proportion in low pay has been relatively stable, with the simple average across the 22 countries covered in both years unchanged.

Turning to the characteristics associated with being low paid, Table 2 focuses on gender. We see that in 2006 low pay rates were higher for women than for men in all the countries covered, often very substantially so. Rates for women were as much as twice those for men in a considerable number of countries, and the gap was even greater than that in Cyprus, the Czech Republic, Estonia, and the UK. It is worth emphasising that this is not being driven by the fact that women are more likely to be working part-time: here we are focused on full-time workers only, and yet the gaps 
are this wide. Comparing the situation in 2013 with 2006, the low pay rate went up particularly sharply for men in Austria, Cyprus, Spain, Poland and the UK; Hungary and Iceland saw large declines for men. For women the more common pattern was decline, with particularly large falls seen in Cyprus, Denmark, Hungary, Iceland and Sweden. This meant that the gender gap in low pay narrowed in countries such as Cyprus Spain, Iceland and the UK.

Table 2: Low Pay by Gender, Full-time Employees

\begin{tabular}{lcccc}
\hline & \multicolumn{2}{c}{2006} & \multicolumn{2}{c}{2013} \\
& men (\%) & women (\%) & men (\%) & women (\%) \\
\hline \hline Austria & 10.8 & 26.2 & 15.6 & 27.8 \\
Belgium & 7.3 & 15.4 & 7.3 & 16.6 \\
Cyprus & 9.2 & 38.9 & 11.8 & 34.9 \\
Czech Republic & 8.9 & 28.7 & 8.3 & 28.1 \\
Germany & 18.5 & 31.1 & 17.6 & 31.6 \\
Denmark & 9.0 & 14.9 & 7.6 & 11.0 \\
Estonia & 12.8 & 32.8 & 11.9 & 32.7 \\
Greece & & & 10.3 & 16.9 \\
Spain & 11.5 & 27.7 & 14.9 & 27.1 \\
Finland & 9.0 & 13.6 & 6.0 & 11.9 \\
France & 8.7 & 14.8 & 8.2 & 13.6 \\
Hungary & 22.2 & 23.4 & 12.4 & 18.2 \\
Ireland & 18.9 & 28.0 & 19.9 & 28.9 \\
Italy & & & 12.7 & 18.0 \\
Iceland & 13.7 & 30.9 & 10.7 & 26.0 \\
Lithuania & 20.6 & 32.9 & 21.7 & 33.4 \\
Luxembourg & 25.1 & 36.1 & 27.0 & 33.0 \\
Latvia & & & 20.9 & 31.1 \\
The Netherlands & 11.4 & 24.5 & 12.3 & 22.7 \\
Norway & 10.0 & 21.0 & 11.5 & 21.1 \\
Poland & 19.2 & 27.7 & 16.8 & 23.7 \\
Portugal & & & 7.7 & 16.7 \\
Sweden & 11.8 & 20.6 & 8.9 & 16.5 \\
Slovenia & 15.7 & 22.5 & 15.8 & 21.0 \\
Slovakia & 9.7 & 22.8 & 10.0 & 23.5 \\
UK & 12.7 & 29.4 & 17.6 & 28.8 \\
\hline \hline
\end{tabular}

Looking at age, Table 3 shows that before the Crisis in most countries the percentage low paid was much higher for those aged under 30 than older workers, in either the 30-44 or 45-64 age groups - exceptions being the Czech Republic, Lithuania and Slovakia, where there was little differentiation by age, and Estonia where the percentage low paid was higher for workers aged 30 or over. The relative 
disadvantage of younger workers was particularly striking in for example the Netherlands, where over $40 \%$ were low paid compared to only $8 \%$ or below for older workers. Comparing 2013 with 2006, we see that the percentage low paid also went up most for younger workers, with very substantial increases in the case of Austria, Cyprus, Denmark, Spain, Ireland and Norway. Low pay rates were generally more stable for those in the older age ranges, with declines for both those between 30-44 and 45-64 in Denmark, Finland, Hungary and Sweden but increases in Luxembourg, the Netherlands and the UK, and a substantial increase for those aged 30-44 in Spain.

Table 3: Low Pay by Age Group, Full-time Employees

\begin{tabular}{lcccccc}
\hline & & 2006 & & & 2013 & \\
& & & & $18-29$ & $30-44$ & $45-64$ \\
$(\%)$ & $(\%)$ & $30-44(\%)$ & $45-64(\%)$ & $(\%)$ & $(\%)$ \\
\hline \hline Austria & 27.3 & 13.1 & 12.3 & 38.7 & 15.1 & 11.7 \\
Belgium & 20.8 & 7.8 & 4.8 & 21.3 & 8.7 & 7.1 \\
Cyprus & 35.9 & 18.7 & 16.1 & 43.1 & 19.9 & 15.1 \\
Czech Republic & 18.5 & 15.9 & 20.3 & 18.9 & 15.7 & 19.5 \\
Germany & 57.4 & 13.7 & 15.9 & 52.7 & 14.6 & 17.9 \\
Denmark & 26.9 & 9.5 & 7.8 & 37.1 & 6.4 & 2.9 \\
Estonia & 16.6 & 20.3 & 32.2 & 17.0 & 18.3 & 33.4 \\
Greece & & & & 34.5 & 10.6 & 7.7 \\
Spain & 29.2 & 13.8 & 13.3 & 38.2 & 19.3 & 14.0 \\
Finland & 22.4 & 9.5 & 8.1 & 23.6 & 6.6 & 6.3 \\
France & 21.3 & 9.0 & 7.5 & 22.9 & 7.4 & 8.6 \\
Hungary & 30.5 & 21.4 & 18.0 & 20.9 & 14.5 & 13.6 \\
Ireland & 40.7 & 15.7 & 13.1 & 56.1 & 19.9 & 14.1 \\
Italy & & & & 30.9 & 13.2 & 11.7 \\
Iceland & 38.1 & 17.1 & 15.6 & 43.7 & 14.3 & 12.2 \\
Lithuania & 25.8 & 26.7 & 27.5 & 27.7 & 28.5 & 26.4 \\
Luxembourg & 55.6 & 24.4 & 10.7 & 40.8 & 27.0 & 22.5 \\
Latvia & & & & 25.0 & 24.6 & 29.6 \\
The Netherlands & 41.4 & 7.6 & 3.8 & 39.8 & 10.1 & 7.1 \\
Norway & 32.6 & 11.8 & 10.0 & 41.7 & 11.8 & 8.2 \\
Poland & 37.0 & 18.8 & 17.8 & 30.2 & 16.4 & 20.1 \\
Portugal & & & & 16.0 & 11.0 & 12.4 \\
Sweden & 31.8 & 14.3 & 8.5 & 33.1 & 10.8 & 3.9 \\
Slovenia & 29.4 & 17.1 & 16.4 & 32.6 & 15.8 & 16.7 \\
Slovakia & 18.4 & 15.7 & 14.4 & 18.8 & 15.6 & 17.0 \\
UK & 32.1 & 14.6 & 18.8 & 35.3 & 17.5 & 20.8 \\
\hline \hline
\end{tabular}

As well as the characteristics of the individual and how that relates to the likelihood of being low paid, the household context, and in particular whether low paid 
individuals are in a position where the household is depending on their earnings, will be crucial when it comes to poverty. To explore this, Table 4 looks at the proportion of low paid workers who are the sole earner in their household, by age. We see that before the Crisis, even among younger low paid workers a substantial proportion often $30-40 \%$ - were the sole earner in the household. Generally speaking that proportion was greater for low paid workers aged 30 or over, with often half these workers being the only earner in the household. (The likelihood that the household would be relying on the low-paid worker's earnings in this fashion would be expected to be higher for the full-time full-year workers we are examining here than for all low-paid workers.)

Table 4: Percentage of Low-paid Workers Who are the Sole Household Earner by Age

\begin{tabular}{|c|c|c|c|c|c|c|}
\hline & \multicolumn{3}{|c|}{2006} & \multicolumn{3}{|c|}{2013} \\
\hline & $18-29(\%)$ & $30-44(\%)$ & $45-64(\%)$ & $18-29(\%)$ & $30-44(\%)$ & $45-64(\%)$ \\
\hline Austria & 23.6 & 46.5 & 43.2 & 40.6 & 55.9 & 49.7 \\
\hline Belgium & 36.1 & 54.2 & 59.4 & 44.6 & 64.3 & 55.7 \\
\hline Cyprus & 22.7 & 33 & 34.6 & 33.3 & 57.6 & 48.2 \\
\hline Czech Republic & 20.4 & 29 & 32.5 & 26.0 & 38.0 & 41.4 \\
\hline Germany & 33.8 & 63.1 & 63 & 36.4 & 59.0 & 71.5 \\
\hline Denmark & 49.9 & 57.2 & 57.9 & 64.9 & 68.0 & 50.5 \\
\hline Estonia & 30.8 & 47.2 & 45.6 & 32.8 & 48.4 & 55.5 \\
\hline Greece & & & & 61.7 & 68.6 & 77.7 \\
\hline Spain & 28.6 & 42 & 42.8 & 44.4 & 61.4 & 66.2 \\
\hline Finland & 56.9 & 46.7 & 45.8 & 62.5 & 59.5 & 73.1 \\
\hline France & 40.2 & 50.4 & 51.5 & 52.3 & 53.8 & 63.4 \\
\hline Hungary & 30 & 44.7 & 38.4 & 26.2 & 44.6 & 46.4 \\
\hline Ireland & 33.4 & 35.3 & 53.4 & 51.7 & 51.0 & 74.4 \\
\hline Italy & & & & 43.1 & 71.4 & 72.8 \\
\hline Iceland & 43 & 46.2 & 42 & 52.6 & 47.0 & 53.6 \\
\hline Lithuania & 41.5 & 41.8 & 43.5 & 35.4 & 38.2 & 51.9 \\
\hline Luxembourg & 28.9 & 46.2 & 45.9 & 43.1 & 52.6 & 52.5 \\
\hline Latvia & & & & 32.2 & 51.3 & 55.5 \\
\hline The Netherlands & 42.9 & 77.5 & 71.7 & 47.3 & 80.3 & 83.4 \\
\hline Norway & 55.5 & 48.1 & 56 & 57.5 & 48.7 & 63.0 \\
\hline Poland & 34.9 & 47.4 & 48.2 & 38.1 & 47.9 & 49.3 \\
\hline Portugal & & & & 42.0 & 40.3 & 57.2 \\
\hline Sweden & 55.1 & 49.8 & 70.7 & 63.9 & 53.2 & 64.3 \\
\hline Slovenia & 23.3 & 29.8 & 33.8 & 39.3 & 43.6 & 45.3 \\
\hline Slovakia & 18.5 & 25.1 & 26.4 & 15.1 & 36.9 & 39.8 \\
\hline UK & 30.8 & 49.7 & 46.6 & 29.2 & 49.3 & 48.4 \\
\hline
\end{tabular}


Then, comparing 2013 with 2006, we see that there has been a marked increase through the Crisis in the proportion of low-paid workers who are the sole earner in the household. This applies across each of the three age ranges distinguished. Spain represents an extreme example, where the proportion of low-paid workers who are the only earner in the household has risen from $29 \%$ to $44 \%$ for those aged under 30 , but from $42 \%$ to $61 \%$ for those aged $30-44$, and from $43 \%$ to $66 \%$ for those aged between 45-64. Ireland and Slovenia are other countries where these proportions rose particularly rapidly, reflecting the overall decline in employment in the recession. Even in Germany, where the impact on employment levels was very limited, the proportion of older low-paid workers who were the sole earner rose. The UK is an exception, with this proportion stable from 2006 to 2013 at each age group.

Logistic regression can be employed to examine more formally the characteristics associated with low pay and how this varies across countries. Regressing the low paid/not dichotomous dependent variable on gender, age group and occupational group, results for 2006 reported in Maitre et al (2012) in the form of odds ratios show that the odds of being low paid were then higher for women than men in every country. For Northern European countries these odds were of the order of 2 or 3, rising to above 4 for the UK and Spain. There was considerable variation among the post-socialist counties, ranging from 3 for Poland and Lithuania up to 7.5 for the Czech Republic and 10 for Cyprus. The odds of being low paid were substantially higher for the 18-29 age group than for older workers, but that gap varied a great deal across countries. The Netherlands and Luxembourg had distinctively high odds ratios for younger workers, whereas differentials were less sharp for the UK, and for a number of the post-socialist counties this odds ratio was quite low or not significant; the Czech Republic and Estonia were the only countries where the odds of being in low pay were higher for older workers. Estimating the corresponding models with data from EU-SUILC 2013, results presented in Maître et al (2016) show a generally similar picture to 2006 in terms of the age and gender patterns. However, differences in the estimated odds ratios for the two years confirm the narrowing in the gender gap in low pay over the period in Cyprus, Spain and the UK; a significant increase the relative disadvantage of younger workers is also seen for Denmark, Ireland, Spain, and Sweden, and some reduction in their odds for the Netherlands wgere the 2006 figure was so remarkably high. 
The odds of being low paid in 2006 were also seen to be strongly related to occupation: those in routine manual occupations were much more likely to be low paid than those in professional and managerial occupations, their estimated odds ratio reaching 10 or higher. The scale of this gap varied and was much higher in for example Luxembourg, Cyprus, the UK, and the Czech Republic than in Austria, France, and the Netherlands. Those in intermediate and lower technical occupations were also more likely to be low paid that those in professional and managerial occupations, but with the odds in this case being from 2 to 4 times as high. Once again this broad pattern is also seen in the corresponding results for 2013; however, the relative disadvantage of those in routine manual occupations worsend over the period in Austria, Denmark, Estonia, Finland, Luxembourg and Slovakia. Other features such as marital status, the number of children in the household, and the number of earners did not show a strong and consistent pattern across countries in their associated with the likelihood of being low paid in either year.

\section{Low Pay and Income Poverty}

Having discussed how many full-time full-year employees, and which ones, are most affected by low pay, we now turn to the relationship between low pay for those individuals and economic disadvantage for their households. We focus first on the relative income poverty risk, the most widely-used measure of poverty, before turning in the next section to a broader concept of economic vulnerability which can also be operationalised using data available in EU-SILC. The measure of relative income poverty employed corresponds to the "at risk of poverty" indicator at the core of the EU's Laeken indicators of social inclusion/exclusion, discussed and used in earlier chapters. It is based on annual household income from all sources in the year before the survey (except in Ireland and the UK), equivalised using the "modified OECD" scale to adjust for household size and composition; the threshold below which the household (and all those living in it) is taken to be "at risk of poverty" is $60 \%$ of median income in the country in question. The measure of low pay we are using here is also based on earnings over a year, but so it is less than perfectly aligned with the income concept used to measure poverty. 
Table 5 shows the overall levels of income poverty for full-time full-year employees, distinguishing those who are low paid and those who are not, in 2006 and 2013. Focusing first on 2006, the poverty risk for all full-time full-year employees was then generally low - in the 2-3\% range for countries such as Belgium, Denmark, Finland, France, Ireland, the Netherlands, Norway, Slovenia, Sweden and the UK. Countries with relatively high rates of $5-6 \%$ at that point included Austria, Cyprus, Estonia, Spain, Lithuania and Poland, with Luxembourg an outlier at 9\%. So in most countries rather few such employees were in households below this poverty threshold.

Table 5: Levels of Income Poverty Risk by Low Pay Status, Full Time Full-Year Employees

\begin{tabular}{|c|c|c|c|c|c|c|}
\hline & \multicolumn{6}{|c|}{$\%$ at risk of poverty } \\
\hline & \multicolumn{3}{|c|}{2006} & \multicolumn{3}{|c|}{2013} \\
\hline & Not Low Paid & Low Paid & All & Not Low Paid & Low Paid & All \\
\hline Austria & 1.9 & 19.5 & 4.8 & 1.1 & 13.6 & 3.6 \\
\hline Belgium & 0.8 & 7.0 & 1.4 & 1.3 & 8.6 & 2.1 \\
\hline Cyprus & 3.4 & 15.4 & 6.0 & 2.3 & 22.0 & 6.9 \\
\hline $\begin{array}{l}\text { Czech } \\
\text { Republic }\end{array}$ & 1.6 & 9.0 & 2.9 & 1.3 & 8.4 & 2.5 \\
\hline Germany & 1.3 & 11.6 & 3.6 & 1.8 & 17.3 & 5.3 \\
\hline Denmark & 0.3 & 10.5 & 1.5 & 0.9 & 16.4 & 2.3 \\
\hline Estonia & 1.3 & 17.2 & 4.9 & 1.3 & 15.0 & 4.4 \\
\hline Greece & & & & 3.7 & 18.5 & 5.7 \\
\hline Spain & 3.7 & 15.7 & 5.8 & 1.6 & 18.4 & 5.0 \\
\hline Finland & 0.5 & 10.0 & 1.5 & 0.4 & 5.7 & .8 \\
\hline France & 1.9 & 12.9 & 3.2 & 2.3 & 17.7 & 3.9 \\
\hline Hungary & 1.9 & 15.0 & 4.8 & 2.1 & 19.2 & 4.7 \\
\hline Ireland & 0.8 & 8.4 & 2.5 & 0.3 & 3.9 & 1.1 \\
\hline Italy & & & & 2.7 & 25.5 & 6.1 \\
\hline Iceland & 1.1 & 15.8 & 4.1 & 0.4 & 10.8 & 2.3 \\
\hline Lithuania & 1.6 & 18.6 & 6.1 & 1.4 & 19.8 & 6.5 \\
\hline Luxembourg & 2.2 & 24.6 & 8.6 & 1.3 & 24.5 & 8.0 \\
\hline Latvia & & & & 1.3 & 21.0 & 6.5 \\
\hline $\begin{array}{l}\text { The } \\
\text { Netherlands }\end{array}$ & 0.9 & 4.0 & 1.3 & 1.8 & 6.0 & 2.4 \\
\hline Norway & 1.0 & 11.5 & 2.5 & 1.0 & 14.0 & 3.1 \\
\hline Poland & 2.8 & 16.6 & 6.0 & 3.0 & 15.4 & 5.5 \\
\hline Portugal & & & & 3.5 & 21.7 & 5.7 \\
\hline Sweden & 1.1 & 15.0 & 3.3 & 0.9 & 16.8 & 2.8 \\
\hline Slovenia & 1.1 & 8.5 & 2.5 & 1.7 & 13.4 & 3.8 \\
\hline Slovakia & 2.4 & 12.4 & 4.0 & 1.5 & 9.6 & 2.8 \\
\hline UK & 1.2 & 9.6 & 2.8 & 1.1 & 9.9 & 3.0 \\
\hline
\end{tabular}


Of course, as already emphasised, full-time full-year employees are distinctive among all employees, and one would expect their poverty rates to be lower than those employed part-time all year or those in and out of employment during the year. Indeed, the indicators of in-work poverty employed by the EU as part of the broader set of Social Inclusion indicators include separately the at risk of poverty rate for fulltime and part-time workers, and for those employed all year as opposed to only part of the year, and these bear out that an enhanced risk of poverty is associated with working part-time or only part of the year.

So how much difference did it make whether the individual earner him or herself was low paid? We can see from Table 5 that in 2006 income poverty was rather a rare phenomenon for full-time full-year employees who were not themselves low paid, with rates of only $1-2 \%$ being common and only Cyprus and Spain having rates of $3 \%$ or higher. On the other hand, those who were low paid generally faced a multiple of that poverty risk in each country, with poverty rates ranging from $4 \%$ in the Netherlands up to $10-15 \%$ in many countries, $17-20 \%$ in Austria, Estonia and Lithuania, and with Luxembourg once again an outlier at 25\%. Table 6 shows how these differences translate into relativities in terms of odds ratios. The greatest disparities in poverty risk between the low paid and other full-time full-year employees were found in Austria, Denmark, Estonia, Finland, Iceland and Sweden, but low-paid employees were always at least four or five times more likely to be in a poor household than their higher-paid counterparts.

Comparing the situation in 2013 with that picture for 2006, one can also see from Table 5 that over this period there has been little or no increase in the poverty risk for all full-time full-year workers on average. (The simple average poverty rate calulated across the 22 countries for which data is available for both years was 3.8\% in 2006 and $3.9 \%$ in 2013.) This reflects the fact that the poverty rate for those who were not low paid, who constitute most of the group, did not rise between the two years in most countries: even in the face of the recession, their poverty rates in 2013 were mostly in the $1-3 \%$ range, and even in Greece that figure was only $4 \%$. Indeed, the poverty rate for these employees fell in some countries, including Spain. It must be noted in this context that the relative income poverty threshold itself fell over this period in the hardest-hit countries such as Greece, Ireland, Portugal and Spain when average 
incomes declined markedly: the fact that relative income poverty did not increase does not mean that living standards were unaffected. Even with those relative thresholds, though, there was some increase in the risk of poverty for the low paid. Their poverty rates averaged across the 22 countries rose from $13 \%$ to $14.6 \%$, with that rate increasing in a majority of countries including quite sharp increases in Cyprus, Germany, Denmark, France, Iceland and Slovenia. There were also cases where it fell, though, such as Austria, Estonia, Finland, Ireland, Poland and Slovakia. As Table 6 brings out, the net result was that the odds of being in a poor household for a low-paid versus other worker went up more often than they went down over the period, with particularly sharp increases in Cyprus, Spain, Iceland, Ireland, Luxembourg, and Sweden.

Table 6: Odds Ratios for Income Poverty Comparing Low Paid with Others, Full-Time Full-Year Employees

\begin{tabular}{lcc}
\hline & 2006 & 2013 \\
\hline \hline Austria & 12.6 & 13.9 \\
Belgium & 9.3 & 7.2 \\
Cyprus & 5.2 & 11.9 \\
Czech Republic & 6.1 & 7.1 \\
Germany & 10.2 & 11.5 \\
Denmark & 38.0 & 21.1 \\
Estonia & 15.6 & 13.8 \\
Greece & & 5.8 \\
Spain & 4.9 & 13.9 \\
Finland & 23.3 & 16.3 \\
France & 7.5 & 9.2 \\
Hungary & 9.2 & 11.2 \\
Ireland & 11.9 & 15.1 \\
Italy & & 12.3 \\
Iceland & 17.7 & 33.0 \\
Lithuania & 14.2 & 17.7 \\
Luxembourg & 14.3 & 24.2 \\
Latvia & & 19.7 \\
The Netherlands & 4.5 & 3.5 \\
Norway & 12.5 & 15.7 \\
Poland & 6.8 & 6.0 \\
Portugal & & 7.6 \\
Sweden & 16.0 & 23.0 \\
Slovenia & 8.0 & 8.9 \\
Slovakia & 5.8 & 7.1 \\
UK & 8.8 & 10.1 \\
\hline \hline
\end{tabular}


What distinguishes low-paid employees who are in poor households from those who are not, and did this change over the course of the Crisis? To tease this out, one can again look first at patterns by gender and age. Table 7 shows that, among the low paid, income poverty rates in 2006 were generally higher for men than women, often very much higher. In Austria, Belgium, Spain, Finland, France, Iceland, Luxemboug Poland and Sweden, for example, the poverty rate for low-paid men was at least twice as high as that for low-paid women, and for Ireland and the UK it was nearly three times as high at that point. Between 2006 and 2013 poverty rates for low-paid men rose in 11 countries while rising for women in 13 countries; they fell for men in 9 countries versus only five for women.

Table 7: Income Poverty for Low Paid by Gender

\begin{tabular}{|c|c|c|c|c|}
\hline & \multicolumn{4}{|c|}{$\%$ income poor } \\
\hline & \multicolumn{2}{|c|}{2006} & \multicolumn{2}{|c|}{2013} \\
\hline & Men (\%) & Women (\%) & $\operatorname{Men}(\%)$ & Women (\%) \\
\hline Austria & 27.4 & 13.7 & 18.3 & 8.5 \\
\hline Belgium & 9.4 & 4.8 & 10.6 & 7.0 \\
\hline Cyprus & 19.8 & 14.0 & 26.8 & 20.5 \\
\hline Czech Republic & 11.3 & 8.1 & 10.9 & 7.5 \\
\hline Germany & 12.7 & 10.1 & 19.6 & 14.9 \\
\hline Denmark & 11.9 & 9.3 & 16.7 & 16.1 \\
\hline Estonia & 15.6 & 17.8 & 8.2 & 17.4 \\
\hline Greece & & & 25.3 & 12.8 \\
\hline Spain & 23.2 & 10.1 & 22.3 & 15.6 \\
\hline Finland & 15.8 & 5.6 & 8.5 & 4.2 \\
\hline France & 19.1 & 7.4 & 24.4 & 12.2 \\
\hline Hungary & 18.8 & 11.0 & 24.5 & 15.2 \\
\hline Ireland & 12.0 & 4.4 & 6.1 & 1.9 \\
\hline Italy & & & 27.8 & 23.0 \\
\hline Iceland & 23.4 & 10.9 & 17.5 & 7.5 \\
\hline Lithuania & 23.7 & 15.3 & 20.1 & 19.6 \\
\hline Luxembourg & 31.0 & 14.2 & 29.2 & 16.3 \\
\hline Latvia & & & 20.2 & 21.5 \\
\hline The Netherlands & 5.3 & 1.3 & 7.1 & 3.7 \\
\hline Norway & 13.9 & 9.9 & 21.2 & 8.9 \\
\hline Poland & 22.7 & 11.4 & 20.3 & 11.6 \\
\hline Portugal & & & 28.5 & 18.5 \\
\hline Sweden & 20.5 & 10.8 & 25.4 & 10.7 \\
\hline Slovenia & 10.4 & 7.1 & 18.0 & 9.5 \\
\hline Slovakia & 15.2 & 11.1 & 12.3 & 8.3 \\
\hline UK & 15.5 & 5.8 & 12.5 & 7.6 \\
\hline
\end{tabular}


While the rates for men and women often moved in the same direction in a given country, Spain was one exception with the rate for men stable but a significant increase for women; the UK was another, wth the rate for men falling while that for women rose. While there was some modest narrowing on average in the poverty gap between low-paid men versus women, the enhanced likelihood of poverty for lowpaid men remained a major feature in 2013 as it had been before the Crisis.

Focusing on poverty risk for the low paid by age, Table 8 shows that in 2006 the poverty risk for the low paid was generally highest in the 30-49 age group, and lowest in the 18-29 one, though with some variation across countries. The highest poverty rate was for those aged 30-49 in 12 of the countries, for the 50-64 category in 5, and

Table 8: Income Poverty by Low Pay by Age Group

\begin{tabular}{lcccccc}
\hline & & \multicolumn{5}{c}{$\%$ income poor } \\
& & 2006 & & 2013 & \\
& $18-29(\%)$ & $30-49(\%)$ & $50-64(\%)$ & $18-29(\%)$ & $30-49(\%)$ & $50-64(\%)$ \\
\hline \hline Austria & 12.6 & 22.3 & 30.2 & 11.9 & 17.5 & 8.5 \\
Belgium & 3.9 & 9.0 & 12.3 & 5.9 & 9.1 & 13.0 \\
Cyprus & 13.0 & 18.0 & 13.0 & 15.8 & 28.2 & 16.6 \\
Czech Republic & 6.4 & 13.2 & 4.7 & 7.4 & 9.6 & 6.9 \\
Germany & 9.2 & 15.4 & 10.4 & 15.7 & 22.3 & 13.5 \\
Denmark & 15.9 & 9.0 & 5.0 & 14.1 & 23.1 & .1 \\
Estonia & 13.3 & 22.5 & 12.2 & 6.9 & 18.8 & 14.0 \\
Greece & & & & 13.3 & 17.6 & 37.5 \\
Spain & 10.4 & 20.0 & 15.9 & 10.7 & 21.2 & 18.7 \\
Finland & 11.8 & 9.3 & 8.9 & 1.2 & 7.3 & 10.4 \\
France & 10.8 & 12.8 & 18.6 & 10.7 & 23.2 & 19.9 \\
Hungary & 11.4 & 19.1 & 9.6 & 13.7 & 19.8 & 22.1 \\
Ireland & 5.4 & 10.9 & 13.5 & 3.7 & 2.6 & 9.0 \\
Italy & & & & 14.2 & 9.9 & 7.3 \\
Iceland & 14.3 & 20.4 & 7.5 & 14.4 & 27.3 & 13.4 \\
Lithuania & 16.2 & 21.4 & 13.0 & 7.1 & 31.1 & 23.9 \\
Luxembourg & 16.9 & 29.1 & 35.8 & 21.4 & 25.6 & 26.0 \\
Latvia & & & & 17.4 & 23.9 & 18.9 \\
The Netherlands & 2.6 & 7.3 & & 1.5 & 13.3 & 2.4 \\
Norway & 19.8 & 7.5 & 6.5 & 22.8 & 8.5 & 3.6 \\
Poland & 11.4 & 21.7 & 13.0 & 12.0 & 18.5 & 13.8 \\
Portugal & & & & 19.1 & 23.0 & 21.1 \\
Sweden & 23.6 & 9.5 & 13.1 & 16.2 & 18.9 & 8.7 \\
Slovenia & 6.1 & 9.8 & 7.5 & 13.0 & 15.4 & 8.1 \\
Slovakia & 6.7 & 17.0 & 7.1 & 3.6 & 11.4 & 10.2 \\
UK & 8.3 & 11.3 & 8.7 & 5.8 & 12.6 & 10.7 \\
\hline \hline
\end{tabular}


for the youngest age group in 4. Comparison with 2013 shows that this age-related pattern in risk was in anything reinforced by that date, with the highest rate being seen for the 30-49 year old group in 18 of the countries at that point.

In addition to individual characteristics, household composition, and in particular the presence or absence of other earners, is likely to play a key role in whether low pay is associated with in-work poverty for the household. To investigate this, Table 9 again shows income poverty rates for low paid individuals by age, but now distinguishing low paid sole earners from those in households with more than one earner - with the figures for 2006 in Table 9a, and those for 2013 in 9b. Focusing first on 2006, it is evident that the sole-earner low paid have very much higher poverty rates than those in multiple-earner households in all cases, across each of the age groupings. Poverty rates for the low paid in multiple earner households varied a good deal across countries, but were often in low single figures. For low paid sole earners, by contrast, poverty rates were often as high as one-third or more. So it is indeed the role which the earnings of the low paid individual play in the household that is critical in determining whether low pay is associated with household poverty. Poverty rates in single-earner households are highest on average for those in the 30-44 age range, but the gap between them and their counterparts in multiple-earner households is quite similar across the age ranges.

By 2013, as we see in Table 9b, poverty rates for the low paid in multiple earner households were higher in some cases but lower in others, and mostly still in single figures. The low paid who were sole earners also faced lower poverty rates in some countries but the cross-country average was still higher, especially for the 30-44 age range. Once again, the nature of the relative income poverty threshold being employed has to be taken into account: with average incomes and levels of social transfers for some groups declining through the recession, those who managed to stay in full-time work throughout the year could be relatively advantaged compared, for example, with the unemployed. Having said that, it is worth highlighting that in 2013 at least one-quarter or one-third of low paid single earners aged 30-44 are at risk of poverty as conventionally measured, despite the best efforts of the social protection and tax systems to support their incomes; this is the case even in the countries 
generally regarded as having the strongest social safety-nets, such as Denmark and Sweden, though Finland and Norway do better.

Table 9a: At Risk of Poverty for Low Paid by Age Group by Number of Earners in the Household, Full-Time Full-Year Employees, 2006

\begin{tabular}{|c|c|c|c|c|c|c|}
\hline & \multicolumn{2}{|c|}{$18-29$} & \multicolumn{2}{|c|}{$30-44$} & \multicolumn{2}{|c|}{$45-64$} \\
\hline & $\begin{array}{l}\text { One } \\
\text { earner }\end{array}$ & $\begin{array}{l}\text { Multiple } \\
\text { earner }\end{array}$ & $\begin{array}{l}\text { One } \\
\text { earner }\end{array}$ & $\begin{array}{l}\text { Multiple } \\
\text { earner }\end{array}$ & $\begin{array}{l}\text { One } \\
\text { earner }\end{array}$ & $\begin{array}{l}\text { Multiple } \\
\text { earner }\end{array}$ \\
\hline Austria & 27.1 & 8.4 & 35.8 & 9.9 & 35 & 20.4 \\
\hline Belgium & 10.9 & 0 & 15.3 & 3.7 & 12.3 & 0 \\
\hline Cyprus & 35.7 & 7.7 & 44.1 & 9.3 & 31.7 & 2.5 \\
\hline Czech Republic & 26.4 & 0.9 & 43.8 & 2.6 & 14.8 & 0.2 \\
\hline Germany & 23.2 & 1.9 & 24.5 & 0.5 & 17.7 & 0.2 \\
\hline Denmark & 25.3 & 0 & 6.8 & 10.7 & 6.2 & 0 \\
\hline Estonia & 30.9 & 4.1 & 43.6 & 5.8 & 26.8 & 1.8 \\
\hline \multicolumn{7}{|l|}{ Greece } \\
\hline Spain & 27.6 & 2.4 & 40.8 & 2.5 & 39.4 & 2.6 \\
\hline Finland & 19 & 1.6 & 13.1 & 2.5 & 14.5 & 6.1 \\
\hline France & 22.3 & 1.6 & 23.3 & 1.4 & 28 & 4.8 \\
\hline Hungary & 29.7 & 3.9 & 36.5 & 6.6 & 19 & 8 \\
\hline Ireland & 11.2 & 1.4 & 22.3 & 2.2 & 23.7 & 1.8 \\
\hline \multicolumn{7}{|l|}{ Italy } \\
\hline Iceland & 26.9 & 5.2 & 33.9 & 14 & 12.9 & 5.4 \\
\hline Lithuania & 35.1 & 3.2 & 38.5 & 8.3 & 28.6 & 6 \\
\hline Luxembourg & 38.5 & 8.2 & 49.3 & 13.3 & 45.3 & 17.9 \\
\hline \multicolumn{7}{|l|}{ Latvia } \\
\hline The Netherlands & 6.1 & 0 & 10.2 & 0 & 3.7 & 0 \\
\hline Norway & 33.6 & 2.1 & 12.5 & 0 & 11.7 & 2.7 \\
\hline Poland & 20.7 & 3.8 & 36.4 & 4.5 & 27.1 & 5.7 \\
\hline \multicolumn{7}{|l|}{ Portugal } \\
\hline Sweden & 36.9 & 4.9 & 15.4 & 1.2 & 15.5 & 4 \\
\hline Slovenia & 15.9 & 1.9 & 24.4 & 1.5 & 15.5 & 3.4 \\
\hline Slovakia & 27.3 & 2.3 & 30.8 & 10.2 & 25.4 & 7.4 \\
\hline UK & 23.4 & 1.8 & 23.9 & 1.3 & 14.1 & 2.4 \\
\hline
\end{tabular}


Table 9b: At Risk of Poverty for Low Paid by Age Group by Number of Earners in the Household, 2013

\begin{tabular}{|c|c|c|c|c|c|c|}
\hline & \multicolumn{2}{|c|}{$18-29$} & \multicolumn{2}{|c|}{$30-44$} & \multicolumn{2}{|c|}{$45-64$} \\
\hline & $\begin{array}{l}\text { One } \\
\text { earner }\end{array}$ & $\begin{array}{l}\text { Multiple } \\
\text { earner }\end{array}$ & $\begin{array}{l}\text { One } \\
\text { earner }\end{array}$ & $\begin{array}{l}\text { Multiple } \\
\text { earner }\end{array}$ & $\begin{array}{l}\text { One } \\
\text { earner }\end{array}$ & $\begin{array}{l}\text { Multiple } \\
\text { earner }\end{array}$ \\
\hline Austria & 28.3 & 0 & 30.8 & .6 & 17.1 & 0 \\
\hline Belgium & 13.1 & 0 & 14.2 & 0 & 9.6 & 17 \\
\hline Cyprus & 25.7 & 11 & 41.2 & 10.6 & 25.1 & 9 \\
\hline Czech Republic & 18.3 & 4 & 21.3 & 2.5 & 14.9 & 1 \\
\hline Germany & 32.9 & 6 & 34.2 & 5.2 & 18.9 & 0 \\
\hline Denmark & 21.7 & .0 & 33.9 & .0 & .2 & 0 \\
\hline Estonia & 17.5 & 2 & 35.3 & 3.4 & 24.9 & \\
\hline Greece & 21.6 & 0 & 24.9 & 1.7 & 45.0 & 12 \\
\hline Spain & 19.4 & 4 & 26.8 & 12.4 & 25.7 & 5 \\
\hline Finland & 1.9 & 0 & 12.2 & 0 & 14.2 & 0 \\
\hline France & 19.9 & 1 & 37.3 & 6.7 & 23.9 & 13 \\
\hline Hungary & 37.0 & 5 & 35.6 & 7.0 & 33.6 & 12 \\
\hline Ireland & 7.1 & 0 & 5.1 & 0 & 12.0 & 0 \\
\hline Italy & 28.6 & 3 & 40.3 & 8.2 & 31.7 & 3 \\
\hline Iceland & 24.0 & 4 & 16.7 & 2.7 & 12.6 & 1 \\
\hline Lithuania & 13.8 & 3 & 55.6 & 9.8 & 22.2 & 4 \\
\hline Luxembourg & 36.8 & 10 & 40.7 & 8.8 & 39.4 & 11 \\
\hline Latvia & 36.7 & 8 & 41.3 & 5.6 & 30.6 & 4 \\
\hline The Netherlands & 3.1 & 0 & 16.6 & 0 & 2.8 & 0 \\
\hline Norway & 33.9 & 8 & 15.4 & 1.5 & 5.7 & 0 \\
\hline Poland & 22.3 & 6 & 30.1 & 7.8 & 23.9 & 4 \\
\hline Portugal & 30.1 & 11 & 44.5 & 8.4 & 31.4 & 7 \\
\hline Sweden & 24.2 & .0 & 23.3 & 14.0 & 13.6 & 0 \\
\hline Slovenia & 24.7 & 5 & 31.7 & 2.8 & 16.0 & 2 \\
\hline Slovakia & 17.2 & 1 & 27.3 & 2.2 & 21.9 & 2 \\
\hline UK & 19.5 & .0 & 21.1 & 4.2 & 20.6 & 1 \\
\hline
\end{tabular}

Regression analysis of the relationship between low pay and relative income poverty in the two years helps to bring out the most important features. Maitre, Nolan and Whelan (2016) present detailed results for linear probability models employing ordinary least squares in which the dependent variable is relative income poverty, scored 1 for those in poverty and 0 for all others, with low pay, gender and age group as explanatory variables, estimated for all (full-time full-year) earners as well as separately for those in multiple earner versus single earner households. The estimated coefficients for the impact of being low paid (controlling for age and gender) on the predicted poverty risk for all employees in 2006 varied from about 0.04 to 0.25 , with an average of 0.12 across the 22 countries for which data was available for that year. The largest effects were in Austria, Luxembourg, and Iceland, whereas the impact 
was relatively low in the Czech Republic, Germany, the Netherlands, Norway and Sweden; there was little evidence of a consistent pattern of high versus low impact being related to welfare regime or the average level of income in the country. The impact of low pay was consistently much weaker for those in multiple earner households, for whom the average effect was only 0.04 , whereas for those in single earner households it averaged 0.22.

The corresponding results with EU-SILC 2013 covering all 26 countries for which data is available produced an average effect of being low paid on poverty risk of 0.14 . The average for the twenty-two counties observed in 2006 was 0.13 , a marginal increase on the 2006 figure of 0.12. Denmark, France, Germany, Sweden and a number of Southern European counties including Italy saw this impact increase, while Austria, Finland, Iceland and Ireland saw declines and the Netherlands remained low. As in 2006, the impact of low pay was substantially weaker for those in multiple earner households, and this effect declined marginally on average over the period. There was in fact also a marginal reduction for the low paid in single earner households in the average effect on poverty risk, from 0.22 to 0.21 . The increase in the average risk for all the low paid then reflects the marked increase through the Crisis in the proportion of low-paid workers who are the sole earner in the household, emphasised earlier. Overall, the extent of change in the effects of low pay on poverty risk over the Crisis was relatively modest and the variation across countries is not easily interpreted in terms of macro characteristics and experiences.

\section{Low Pay and Economic Vulnerability}

Having discussed the relationship between low pay and household poverty for fulltime full-year workers, it is also of interest to look at a more encompassing measure of household-level economic disadvantage, which we term "economic vulnerability". The limitations of relative poverty measures based solely on income are coming to be widely recognised. These relate not only to the issues that arise in recession when these thresholds may actually fall, as noted earlier, but also those faced when applying purely country-specific standards of reference across countries at very different levels 
of average income, ${ }^{2}$ and, more broadly to the extent to which unidimensional approaches can capture the multidimensional nature of social exclusion (on which see Nolan and , , 2007, 2011).

Vulnerability is a concept which is now being employed in a variety of settings, for example by the World Bank and other multilateral organisations, and has some appeal in this context. Following Chambers (1989), vulnerability can be defined as not necessarily involving current deprivation but rather insecurity and exposure to risk and shock. It can be seen as implicitly involving a multidimensional and dynamic perspective that is consistent with the notion of social exclusion as a process rather than simply an outcome. As Moisio (2004) notes, implicit in the notion of multidimensional measurement of exclusion is the assumption that there is no one 'true' indicator of the underlying concept, but rather a sample of indicators that tap different aspects. A multidimensional approach to the operationalisation of this concept using latent class analysis has been developed and implemented in our earlier work (for example Whelan and Maître, 2005a and b, 2010, Whelan, Nolan and Maître, 2013), and is employed here.

In applying latent class analysis, each of a set of indicators is taken as an imperfect measure of the underlying latent variable economic vulnerability. Here we use as indicators:

1) whether the household is below the $60 \%$ of median relative income poverty threshold,

2) whether it scores above a threshold of three or more out of 7 items on a deprivation index of everyday consumption items, ${ }^{3}$ and

3) whether it reports difficulty in 'making ends meet'.

The objective is to identify groups who are vulnerable in the sense of being distinctive in the risk of falling below a critical resource level, being exposed to consumption

\footnotetext{
${ }^{2}$ This assumed increasing prominence in EU debates after the 2004 and subsequent enlargements to include countries with relatively low average income levels, substantially increasing the variation in income per head across the EU (see for example Fahey, 2007).

${ }^{3}$ These items are not being able to afford a week's annual holiday away from home; incapacity to face unexpected financial expenses; not affording a meal with meat, chicken or fish (or vegetarian) every second day; not affording a car; inability to keep the home adequately warm; not affording a PC; and being in arrears with respect to mortgage, rent, utility bills or hire purchase.
} 
deprivation and experiencing subjective economic stress. While the income aspect of this vulnerability measure is relative in the sense of being framed vis-à-vis the median for the country in question, the same deprivation items and threshold are used in all the countries. Thus it can be seen as "quasi-relative", incorporating both differences in absolute living standards and in within-country relativities, which may be an advantage in capturing the complexity of poverty and exclusion in the enlarged EU. (The headline EU target adopted in 2010 for reducing poverty and social exclusion by 2020 is 'quasi-relative' in the same sense, combining as it does three elements; the same country-specific relative income poverty measure, a similar deprivation measure (though the items employed are not identical), and an indicator of household worklessness - see for example the discussion in Whelan and Maître, ??.)

Table 10 shows the percentage of employees living in households categorised as economically vulnerable on this basis, and distinguishes the low-paid from those not low paid, once again both for 2006 and 2013. Focusing first on the pre-Crisis situation in 2006, we see that the level of economic vulnerability for all employees ranged from $3-4 \%$ in Belgium, Denmark and Finland up to over 20\% in Hungary and Slovakia, reaching 28\% in Cyprus and Poland. Levels of economic vulnerability were higher than relative income poverty in every country other than Luxembourg, as the comparison with Table 5 above brings out. However, the divergence was much greater in some countries than in others - the percentage vulnerable was 1.5 or 2 times the at-risk-of-poverty rate in countries such as Austria, Estonia, Spain, the Netherlands and UK, but 4 times as great or more in Cyprus, the Czech Republic, Poland, Slovenia and Slovakia. 
Table 10: Levels of Economic Vulnerability by Low Pay Status for Full Time Employees

\begin{tabular}{|c|c|c|c|c|c|c|}
\hline & \multicolumn{6}{|c|}{ Economically vulnerable (\%) } \\
\hline & \multicolumn{3}{|c|}{2006} & \multicolumn{3}{|c|}{2013} \\
\hline & $\begin{array}{l}\text { Not Low } \\
\text { Paid }\end{array}$ & Low Paid & $A / l$ & $\begin{array}{c}\text { Not Low } \\
\text { Paid }\end{array}$ & Low Paid & All \\
\hline Austria & 5.8 & 13.6 & 7.1 & 4.6 & 16.0 & 6.9 \\
\hline Belgium & 3.4 & 10.3 & 4.1 & 4.1 & 22.0 & 6.0 \\
\hline Cyprus & 23.2 & 45.2 & 28.1 & 20.7 & 49.8 & 27.5 \\
\hline Czech Republic & 9.7 & 25.7 & 12.6 & 8.7 & 24.3 & 11.4 \\
\hline Germany & 8.0 & 26.7 & 12.1 & 4.8 & 17.4 & 7.6 \\
\hline Denmark & 2.3 & 11.1 & 3.3 & 2.6 & 23.0 & 4.4 \\
\hline Estonia & 3.4 & 22.4 & 7.7 & 5.4 & 22.5 & 9.3 \\
\hline Greece & & & & 22.1 & 49.2 & 25.6 \\
\hline Spain & 7.8 & 20.3 & 10.0 & 7.5 & 25.5 & 11.1 \\
\hline Finland & 3.2 & 8.8 & 3.8 & 3.0 & 12.9 & 3.9 \\
\hline France & 5.9 & 16.2 & 7.0 & 5.5 & 18.5 & 6.8 \\
\hline Hungary & 17.5 & 36.7 & 21.9 & 27.8 & 56.1 & 32.1 \\
\hline Ireland & 2.7 & 16.1 & 5.7 & 9.1 & 21.7 & 12.1 \\
\hline Italy & & & & 13.3 & 39.1 & 17.1 \\
\hline Iceland & 7.9 & 17.3 & 9.8 & 2.6 & 6.1 & 3.2 \\
\hline Lithuania & 12.0 & 37.8 & 18.9 & 7.5 & 30.5 & 13.9 \\
\hline Luxembourg & 0.6 & 9.3 & 3.1 & 2.1 & 18.2 & 6.7 \\
\hline Latvia & & & & 19.3 & 46.6 & 26.4 \\
\hline The Netherlands & 2.5 & 4.5 & 2.8 & 3.5 & 11.1 & 4.6 \\
\hline Norway & 2.4 & 8.4 & 3.3 & 1.0 & 6.1 & 1.7 \\
\hline Poland & 22.4 & 48.8 & 28.5 & 11.1 & 28.9 & 14.6 \\
\hline Portugal & & & & 16.7 & 34.5 & 18.9 \\
\hline Sweden & 2.7 & 6.8 & 3.3 & 1.0 & 3.0 & 1.3 \\
\hline Slovenia & 6.5 & 19.8 & 9.0 & 9.1 & 28.1 & 12.6 \\
\hline Slovakia & 16.6 & 36.8 & 19.9 & 10.2 & 21.8 & 12.1 \\
\hline UK & 4.2 & 13.4 & 6.0 & 5.0 & 16.8 & 7.2 \\
\hline
\end{tabular}

Within countries, we then see that low paid employees were much more likely to be in vulnerable households than those who are not low paid. As highlighted by the odds ratios shown in Table 11, the low paid were generally 3 or 4 times as likely as the non-low-paid to be in vulnerable households in 2006. This is a marked difference between the low paid and others, but mostly much more modest than the gap between them in income poverty risk, as seen from the comparison with the corresponding odds ratios relating to poverty risk in Table 6 . The proportion of the low paid who were vulnerable is a good deal higher than the proportion at risk of poverty - on average across the countries, the likelihood of being vulnerable for the low paid is about twice that of being at risk of poverty. However, the odds ratios are generally 
lower in the case of vulnerability because employees who were not low paid were much more likely to be in vulnerable households than they were to be at risk of poverty. Whereas the cross-country average poverty rate for employees who were not low paid was only about $1 \%$, the corresponding figure for vulnerability was about $10 \%$.

Table 11: Odds Ratios for Economic Vulnerability by Low Pay, Full-Time Full-Year Employees

\begin{tabular}{lcc}
\hline & 2006 & 2013 \\
\hline \hline Austria & 2.5 & 3.9 \\
Belgium & 3.3 & 6.7 \\
Cyprus & 2.7 & 3.8 \\
Czech Republic & 3.2 & 3.4 \\
Germany & 4.2 & 4.2 \\
Denmark & 5.2 & 11.4 \\
Estonia & 8.3 & 5.1 \\
Greece & & 3.4 \\
Spain & 3.0 & 4.2 \\
Finland & 2.9 & 4.7 \\
France & 3.1 & 3.9 \\
Hungary & 2.7 & 3.3 \\
Ireland & 6.9 & 2.8 \\
Italy & & 4.2 \\
Iceland & 2.4 & 2.4 \\
Lithuania & 4.5 & 5.4 \\
Luxembourg & 16.1 & 10.5 \\
Latvia & & 3.6 \\
The Netherlands & 1.8 & 3.4 \\
Norway & 3.7 & 6.4 \\
Poland & 3.3 & 3.3 \\
Portugal & & 2.6 \\
Sweden & 2.6 & 3.1 \\
Slovenia & 3.6 & 3.9 \\
Slovakia & 2.9 & 2.4 \\
UK & 3.5 & 3.9 \\
\hline \hline
\end{tabular}

Comparing 2006 and 2013, we can see from Table 10 that the overall percentage of full-time full-year employees in vulnerable households rose through the Crisis in Hungary, Ireland, Iceland and Slovenia, both for low-paid employees and those who are not low-paid. However, vulnerability rates were a good deal lower in 2013 than they had been in 2006 in countries such as Lithuania and Poland, which saw substantial declines in deprivation in particular, and were also down in Germany. 
In most countries it is still only a minority of the low paid who are in vulnerable households, so once again the characteristics associated with a higher or lower probability of being in that situation are of significant interest. The proportion vulnerable is generally higher for low-paid men than women, as was true of income poverty, but the differences between them are more modest. In age terms economic vulnerability is most often highest for the 30-49 age category, but the variation across age groups is once again rather more limited than in the case of income poverty. Finally, as in the case of income poverty, where the low paid individual is sole earner in the household they are much more likely to be in a vulnerable household, as can be seen for 2013 from Table 12. However, their enhanced risk is again much less than was the case for income poverty - sole earners are on average about twice as likely as multiple earners to be vulnerable. This reflects the fact that rates of vulnerability are much higher than rates of income poverty for multiple earner households: whereas poverty rates for households are often in low single figures even after the Crisis, as we saw in Table 9, but their rates of economic vulnerability are often $20 \%$ or above. 
Table 12: Economic Vulnerability for Low Paid by Age Group by Number of Earners in the Household, Full Time Employees

\begin{tabular}{|c|c|c|c|c|c|c|}
\hline & \multicolumn{6}{|c|}{2013} \\
\hline & \multicolumn{2}{|c|}{$18-29$} & \multicolumn{2}{|c|}{$30-44$} & \multicolumn{2}{|c|}{$45-64$} \\
\hline & $\begin{array}{l}\text { One } \\
\text { earner }\end{array}$ & $\begin{array}{l}\text { Multiple } \\
\text { earner }\end{array}$ & $\begin{array}{l}\text { One } \\
\text { earner }\end{array}$ & $\begin{array}{l}\text { Multiple } \\
\text { earner }\end{array}$ & $\begin{array}{l}\text { One } \\
\text { earner }\end{array}$ & $\begin{array}{l}\text { Multiple } \\
\text { earner }\end{array}$ \\
\hline Austria & 21.9 & 4.6 & 26.7 & 15.7 & 28.5 & 0.0 \\
\hline Belgium & 25.9 & 3.0 & 32.7 & 17.1 & 31.5 & 22.4 \\
\hline Cyprus & 54.0 & 43.8 & 64.6 & 37.1 & 54.8 & 36.4 \\
\hline $\begin{array}{l}\text { Czech } \\
\text { Republic }\end{array}$ & 49.2 & 18.6 & 37.9 & 18.9 & 33.3 & 9.9 \\
\hline Germany & 23.3 & 8.0 & 31.6 & 9.7 & 21.3 & 6.0 \\
\hline Denmark & 18.7 & 8.0 & 45.1 & 14.8 & 27.8 & 0.0 \\
\hline Estonia & 30.5 & 8.8 & 45.2 & 9.7 & 30.2 & 8.5 \\
\hline Greece & 59.5 & 12.5 & 58.7 & 31.2 & 67.7 & 64.8 \\
\hline Spain & 22.9 & 8.5 & 34.6 & 20.6 & 27.7 & 22.8 \\
\hline Finland & 16.6 & 5.4 & 24.5 & 1.7 & 11.9 & 4.7 \\
\hline France & 18.1 & 7.3 & 38.7 & 8.7 & 24.3 & 3.4 \\
\hline Hungary & 66.3 & 48.5 & 64.2 & 49.5 & 61.9 & 55.6 \\
\hline Ireland & 34.5 & 10.0 & 32.1 & 6.8 & 35.4 & 0.0 \\
\hline Italy & 40.9 & 18.3 & 51.5 & 14.7 & 53.8 & 26.4 \\
\hline Iceland & 18.9 & 1.2 & 6.6 & 4.1 & 1.0 & 1.7 \\
\hline Lithuania & 19.7 & 24.6 & 52.3 & 20.2 & 43.0 & 18.7 \\
\hline Luxembourg & 27.1 & 3.3 & 23.6 & 16.7 & 24.1 & 13.9 \\
\hline Latvia & 61.1 & 30.7 & 63.3 & 32.7 & 61.0 & 30.1 \\
\hline $\begin{array}{l}\text { The } \\
\text { Netherlands }\end{array}$ & 2.4 & 5.8 & 21.8 & 9.0 & 13.8 & 12.0 \\
\hline Norway & 9.1 & 1.8 & 13.4 & 1.9 & 4.3 & 0.0 \\
\hline Poland & 33.1 & 17.8 & 40.6 & 16.3 & 52.7 & 23.1 \\
\hline Portugal & 42.3 & 19.4 & 56.6 & 22.6 & 46.9 & 19.1 \\
\hline Sweden & 2.7 & 1.8 & 5.2 & 0.0 & 7.5 & 7.1 \\
\hline Slovenia & 41.4 & 23.7 & 42.8 & 14.1 & 34.7 & 24.5 \\
\hline Slovakia & 45.7 & 16.0 & 34.6 & 16.2 & 32.8 & 12.3 \\
\hline UK & 34.1 & 8.7 & 27.1 & 11.4 & 22.0 & 8.1 \\
\hline
\end{tabular}

Once again regression analysis, now of the relationship between low pay and economic vulnerability, in the two years helps to bring out the most important features, drawing on the detailed results presented in Maître, Nolan and Whelan (2016). The estimated linear probability models show that, controlling for age and gender, the low paid are at greater risk of vulnerability than employees who are not low paid in all countries. However, in the more affluent Northern European countries (with the exception of the Netherlands, Ireland and Germany) this impact is considerably less than was the case for income poverty, with the estimated coefficients being only half as large on average. For the southern and eastern 
countries, by contrast, where economic vulnerability levels are themselves substantially higher, the estimated impact of low pay is almost double that on income poverty on average. So there is a substantial difference in the respective impact of low pay on economic vulnerability versus poverty in low and high vulnerability countries. As with income poverty, the impact of low pay on vulnerability is substantially weaker for those in multiple earner versus single earner households, but the contrast between country groupings is most striking for those in multiple earner households. In the more affluent Northern European countries the average effect on vulnerability of being low paid in a multiple earner household was less than a quarter of the corresponding effect for income poverty, whereas in southern and eastern European countries the average effect on vulnerability for these households was three times higher than that on poverty.

The corresponding results for 2013 show some narrowing of the overall gap between the affluent Northern European countries and the rest in these terms, with the average effect of low pay on vulnerability going up in the former but remaining stable in the latter. This reflected some increase in the impact of low pay on vulnerability for both single and more particularly multiple earner households in a number of the the Northern European countries, and some decline in the impact for both groups in a number of eastern European countries. However, there was a good deal of variation across countries within both groupings, and

\section{Conclusions}

This chapter has investigated the extent of low pay for full-time full-year employees across European countries, and examined the relationship between low pay and both household poverty and a broader measure of economic vulnerability for these workers. Part-time workers and those in and out of work during the year are more likely to experience poverty, but those who are working full-time for the whole year and still not managing to avoid poverty or vulnerability constitute a group of particular interest and concern. By employing a measure of low annual earnings for those in full-time employment throughout the year available for most countries from EU-SILC, the extent and nature of low pay, poverty and vulnerability for these workers can be assessed. 
In 2006, before the onset of the economic Crisis, the percentage of these full-time full-year employees below a two-thirds of median earnings threshold varied across countries from $10 \%$ up to almost $30 \%$. In terms of the welfare regimes, countries from the social democratic regime generally had relatively low rates, while corporatist counties generally had higher but still relatively low levels (although Germany and Luxembourg were exceptions). Ireland and the UK, representatives of the liberal regime, were above average, as were Spain and Cyprus (the only 'Southern' countries for which the data reqired was available for 2006), while there was a good deal of variation among the post-socialist countries.

Comparing 2013 with 2006, what is striking is that the pattern of low pay for these workers is so similar, despite the economic turmoil in the intervening years. The extent of low pay was rather stable in a majority of countries, and where there was change then countries where it increased are balanced by ones registering a decline. The likelihood of being low paid was generally higher for women than for men, and for young than for older workers, in both years.

Looking at the relationship between employee pay and household income poverty, measured vis-à-vis relative income thresholds, then before the Crisis such poverty was a rare phenomenon for employees who were not low paid. Low paid employees, however, faced a much higher poverty risk, being often at least four or five times more likely to be in a poor household than their better-paid counterparts. Comparing the situation in 2013 with 2006, there was little or no increase in the poverty risk for full-time full-year workers who are not low paid: even in the face of the recession, their poverty rates in 2013 were mostly in the 1-3\% range, and even in Greece that figure was only $4 \%$. Indeed, the poverty rate for these employees fell in some countries, including Spain. It must be noted in this context that the relative income poverty threshold itself fell over this period in the hardest-hit countries such as Greece, Ireland, Portugal and Spain when average incomes declined markedly: the fact that relative income poverty did not increase does not mean that living standards were unaffected. Even with those relative thresholds, though, there was some increase in the risk of poverty for the low paid, with their poverty rate increasing in a majority of countries including quite sharp increases in Cyprus, Germany, Denmark, France, Iceland and Slovenia. 
In both 2006 and 2013, the likelihood of a low paid worker being in a household below the at-risk-of-poverty income threshold was seen to be linked to gender, age and in particular the presence or absence of other earners. Sole-earner low paid employees had very much higher poverty rates than those in multiple-earner households in all countries in both years. Poverty rates for the low paid in multiple earner households vary a good deal across countries, but are often in low single figures even after the Crisis, whereas for low paid sole earners poverty rates are often as high as one-third or more.

Finally, the relationship between low pay and a broader concept of economic vulnerability was analysed, complementing income-based poverty measures. While in most countries only a minority of low paid individuals are in vulnerable households, this minority was considerably larger than the proportion at risk of poverty, especially in the new EU member states. The extent of economic vulnerability for low-paid workers also increased between 2006 and 2013 in a considerable number of countries. Both before the Crisis and in 2013, the structuring of vulnerability was associated with gender and age, though these relationships appear more attenuated than is the case for income poverty risk, and once again the number of earners in the household is key. 


\section{References}

Atkinson, A.B. (2008) The Changing Distribution of Earnings in OECD Countries, Oxford: Oxford University Press.

Autor, D., Levy, F. and Murnane, R. (2003) "The Skill Content Of Recent Technological Change: An Empirical Exploration”, The Quarterly Journal of Economics, 118 (4), 1279-1333.

Blau, F. and Kahn, L. (1996). "International Differences in Male Wage Inequality: Institutions Versus Market Forces”, Journal of Political Economy, 104 (4), 791-837.

Card, D. and DiNardo, J. (2002) "Skill-Biased Technological Change and Rising Wage Inequality: Some Problems and Puzzles", Journal of Labor Economics, 20, 733-83.

Chambers, R. (1989). "Editorial Introduction: Vulnerability, Coping and Policy." IDS Bulletin 20(2): 7.

DiNardo, J. and Lemieux, T. (1997). "Diverging Male Wage Inequality in the United States and Canada, 1981-1988: Do Institutions Explain the Difference?", Industrial and Labor Relations Review, 50 (4), 629-651

DiNardo, J., Fortin, N. and Lemieux, T. (1996) "Labor Market Institutions, and the Distribution of Wages, 1973-1992: A Semiparametric Approach," Econometrica 64, 1001-1044.

European Commission (2004): Employment in Europe 2004: Recent Trends and Prospects, Office of the Official Publications of the EC: Luxembourg.

Fahey, T. (2007), "The Case for an EU-wide Measure of Poverty", European Sociological Review, 23, 1, 35-47.

Freeman, R. and Katz, L. (1995). Differences and Changes in Wage Structures, Chicago: University of Chicago Press.

Gautié, J. and Schmitt, J. eds (2009) Low Wage Work in the Wealthy World, Russell Sage Foundation: New York.

Goos, M. and A. Manning (2007), "Lousy and Lovely Jobs: The Rising Polarization of Work in Britain", Review of Economics and Statistics, 89 (1), 118-133

Gießelmann, M. and Lohman, H. (2008), "The different roles of low-wage work in Germany" in Andre $\beta$, H.-J. and Lohman, H. eds. The Working Poor in Europe: Employment, Poverty and Globalization, Edward Elgar: Cheltenham.

Lemieux, T. (2008), 'The Changing Nature of Wage Inequality', Journal of Population Economics, 21, 21-48. 
Lohman, H. (2008), "The working poor in European welfare states: empirical evidence from a multilevel perspective"', in Andress, H.-J. and Lohman, H. eds. The Working Poor in Europe: Employment, Poverty and Globalization, Edward Elgar: Cheltenham.

Lohman, H. and Marx, I. (2008), "The different faces of in-work poverty across welfare state regimes", in Andre $\beta$, H.-J. and Lohman, H. eds. The Working Poor in Europe: Employment, Poverty and Globalization, Edward Elgar: Cheltenham.

Lucifora, C. (2000), "Wage Inequalities and low Pay: The Role of Labour Market Institutions", in M. Gregory, W. Salverda and S. Bazen eds., Labour Market Inequalities: Problems and Policies of Low-wage Employment in International Perspective, Oxford University Press: Oxford.

Maître, B., Nolan, B. and Whelan, C.T. (2012), 'Low Pay, In-Work Poverty and Economic Vulnerability: A Comparative Analysis Using EU-SILC', The Manchester School, 80 (1), 99-116.

Maître, B., Nolan, B. and Whelan, C.T. (2013), A critical evaluation of the EU 2020 poverty and social exclusion target: an analysis of EU-SILC 2009, Geary Institute Working Paper WP2013/09, Dublin: UCD.

Maître, B., Nolan, B. and Whelan, C.T. (2016), Low Pay, In-Work Poverty and Economic Vulnerability in Europe Through the Economic Crisis, Geary Institute /ESRI Working Paper, Dublin.

Marx, I. and Verbist, G. (2008), "When famialism fails: the nature and causes of inwork poverty in Belgium", in Andre $\beta$, H.-J. and Lohman, H. eds. The Working Poor in Europe: Employment, Poverty and Globalization, Edward Elgar: Cheltenham.

Moisio, P. (2004), "A latent class application to the multidimensional measurement of poverty", Quantity and Quality-International Journal of Methodology, 38(6), 703717.

Nolan, B. and Marx, I. (2000), "Low Pay and Household Poverty", in M. Gregory, W. Salverda and S. Bazen eds., Labour Market Inequalities: Problems and Policies of Low-wage Employment in International Perspective, Oxford University Press: Oxford.

Nolan, B., Salverda, W., Maître, B. and Mühlau, P. (2000), Low Wage and High Wage Employment in Europe: Results from New European Datasets and National Data, Report

Nolan, B. and Whelan, C.T. (2007), "On the Multidimensionality of Poverty and Social Exclusion”, in J. Micklewright and S.P. Jenkins (eds.), Inequality and Poverty Re-examined, Oxford University Press: Oxford.

OECD (1996), "Earnings Inequality, Low-paid Employment and Earnings Mobility", in Employment Outlook, OECD: Paris. 
OECD (2008), Growing Unequal? Income Distribution and Poverty in OECD Countries, OECD: Paris.

Whelan, C. T. and Maître, B. (2005a), "Vulnerability and multiple deprivation perspectives on economic exclusion in Europe: A latent class analysis", European Societies, 7(3), 423-450.

Whelan, C. T. and Maître, B. (2005b), Economic exclusion, multidimensional deprivation and social integration in an enlarged European Union, International Journal of Comparative Sociology. 46, 215-239.

Whelan, C. T. and Maître, B. (2010), 'Welfare Regime and social class variation in poverty and economic vulnerability in Europe: an Analysis of EU-SILC', Journal of European Social Policy, 20 (4): 316-332.

Whelan, C. T., Nolan, B. and Maître, B. (2013) 'Analysing Intergenerational Influences on Income Poverty and Economic Vulnerability with EU-SILC'. European Societies, 15 (1): 82-105. 